\title{
BELT CONVEYOR EQUIPPED BY VIBRATION ENERGY HARVESTING DAMPER
}

\author{
(C) George Nerubenko ${ }^{1}$, Vitaliy Krupenin ${ }^{2}$, Dmytriy Gurevych ${ }^{3}$ \\ ${ }^{1} N E R *$ MAR Limited, Canada \\ optimalproject@hotmail.com, \\ ${ }^{2}$ IMASH RAN, Russia \\ krupeninster@gmail.com \\ ${ }^{3}$ Mega Automation Inc, Canada \\ dgurevych@mega-automation.ca
}

\begin{abstract}
The belt conveyor functioning is accompanied by aggressive vibrations during work in the agricultural environment. The most important is the discharge point where the transporting products leave a belt. The vibrations reduce the accuracy of the automatic product handling process. It was necessary to solve three interconnected problems of a conveyor: the accurate automatic detection of an exit product position, a reduction of intensive vibrations and the proper usage of damped vibration energy. The considered example of an automatic system for robotic handling and / or manipulating of the exit objects (products) includes a belt conveyor, the laser vision sensor arrays, operational arm and vibration energy harvesting dampers. The vibration energy harvesting dampers are invented by authors and installed at exit of a conveyor. Such installation configuration gives the opportunity to eliminate the vibrations at discharge area and convert the damped vibration energy into electrical power. The theoretical modeling was verified by experiments. Test results prove the concept proposed in study and confirm the efficiency of the proposed systems for optimizing of belt conveyor operation.
\end{abstract}

Keywords: belt conveyor, vibration energy harvesting damper.

\section{ЛЕНТОЧНЫЙ КОНВЕЙЕР, СНАБЖЕННЫЙ ВИБРАЦИОННЫМ ДЕМПФЕРОМ И ПРЕОБРАЗОВАТЕЛЕМ ЭНЕРГИИ}

\author{
(C) Виталий Львович Крупенин ${ }^{1}$, Георгий Петрович Нерубенко ${ }^{2}$, Дмитрий Юрьевич \\ Гуревич ${ }^{3}$ \\ ${ }^{1} N E R *$ MAR Limited, Kaнадa \\ optimalproject@ hotmail.com \\ ${ }^{2}$ Институт машиноведения им. А.А. Благонравова, Москва, Россия \\ krupeninster@gmail.com \\ ${ }^{3}$ Mega Automation Inc, Канада \\ dgurevych@mega-automation.ca
}

\begin{abstract}
Аннотация. Функционирование ленточного конвейера сопровождается агрессивными вибрациями во время сельско-хозяйственных работ. Наиболее важным является район выхода конвейера, где транспортируемый продукт покидает ленту. Вибрации уменьшают точность прочесса автоматической обработки продукта. Было необходимо решить три взаимосвязанные проблемы конвейера: точное автоматическое определение положения 20
\end{abstract}


продукта, покидающего ленту, снижение интенсивных вибраџий и надлежащее использование демпфируемой вибрационной энергии. Рассматриваемый пример автоматической системы роботизированной обработки и/или манипулирования объектами (продуктами) покидающими ленту, включает в себя ленточный конвейер, систему лазерного видения, операчионную руку и вибрачионные демпферы, снабженные преобразователями энергии. Вибрационные демпферы, снабженные преобразователями энергии, изобретень авторами и установлены на выходе конвейера. Подобная конфигурация установки даёт возможность уменьшить вибрации на выходе из конвейера и преобразовать энергию устранённых вибрачий в электричество. Теоретическое моделирование было проверено экспериментально. Результаты испытаний подтвердили концепщию, предложенную при исследованиях, и доказали эффективность предложенной системы для оптимизации работы ленточного конвейера.

Ключевые слова: ленточный конвейер, вибраџионный демпфер, снабженный преобразователем энергии.

The influence of severe vibrations must be reduced during operations of the belt conveyor. The discharge area of a conveyor is the most critical region where vibration suppression is needed. The robotic arm $[1 ; 2]$ is operating at this area, so it is very important to provide all necessary measures for ideal operation. Such measures have to secure the fast performance of belt conveyor (equipped by electromechanical robotic system) with a perfect accuracy or minimize system energy consumption. The study of vibration suppression combined with parallel generation of the electrical power (energy harvesting) using suppressed vibrations is presented. The today technology is widely using the energy harvesting units having a certain oscillating weight allowing (in parallel to vibration mitigation) capture, convert and transfer some amount of wasted power, however the authors would concentrate on their own R\&D [3-6], [12]. The authors invented and developed Vibration Energy Harvesting Dampers (VEHD) consisting of tuned mass damper (TMD) and an alternator or generator of electricity. The specific of proposed VEHD is to provide self-tuning to dampen harmonics over a wide interval of fluctuated frequencies using the control system of TMD. The purpose of this study is to demonstrate the benefits of VEHD implanting into belt conveyorfeeder system for rising the operation efficiency and keeping the high accuracy of an arm functioning.

Major schemes and functional components of a proposed electromechanical system were synthesized in [1 - 12]. It is necessary to point out the proposed system is a sort of the universal one. The developed approach is applicable in various industries, like agriculture (as discussed here), metal plate packing and handling, furniture sheets cut out and shaping and so on. The proposed approach allows take into an account the inertia forces, aerodynamic resistance, mechanical properties of handling materials and configurations, etc. Such approach gives the opportunity to provide fast performance with perfect accuracy or minimize energy consumption. A schematic composition of proposed system is in Fig. 1. The belt conveyor 1 has the transporting load 2 (bins, bags, sheets, plates, boxes, etc) on its working surface at discharge area. The arm 3 has to capture load 2 (lift up / relocate / reload / or to do something else) in accordance to required technological program. An accelerometer 4 (which could measure the vibrations in 3D) is located in a discharge area of the considered belt conveyor-feeder. The laser vision system 5 is sending its information to the data analyzing and movement planning unit 6 .

One stream of signals from unit 6 is going to unit 7 for formulation of the arm movements. A signal from unit 7 is coming to block 8 for transformation of the arm's coordinates and then going to unit 9 for the interpolation. After that a signal from unit 9 is running to unit 10 for a program correlation. 
The unit 10 delivers the signal to the actuator 11 serving an arm 3 and a conveyor's motor 12 . The purpose of described subsystem is to increase an accuracy of the arm operation. Here the authors must note that the presented chain is a general one: some units could be combined; other units could be split into more detailed components. However, the main logic is directed in it.

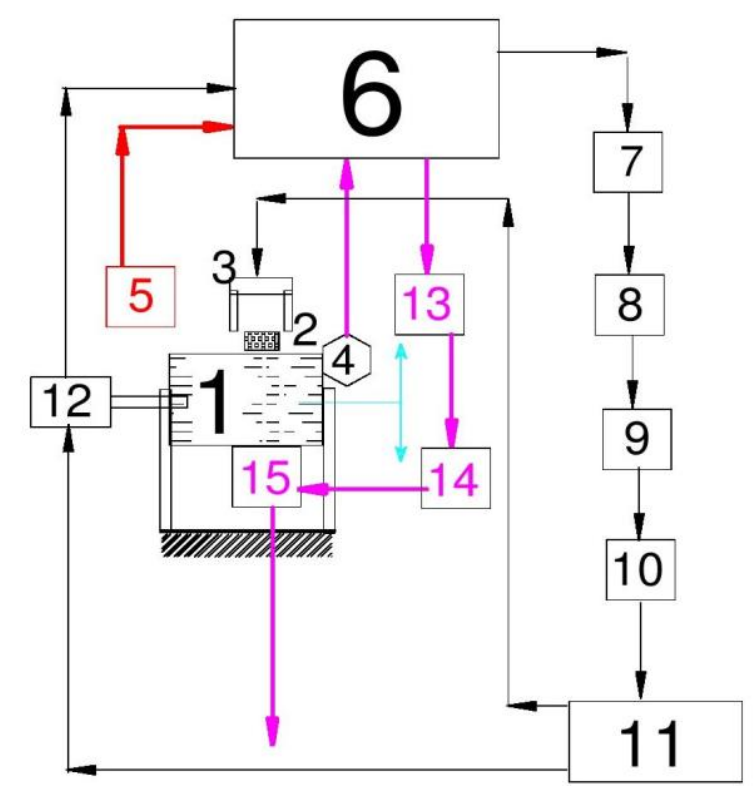

Fig. 1. Graphical presentation of a system general composition

The signal sent by an accelerometer 4 is treated in unit 6 and then goes to commander 13, where the commands are built for actuator 14. An actuator 14 is servicing the VEHD 15, which is suppressing the conveyor vibrations and generate electrical power that is directing or to separate source of energy of to grid (not shown in Fig. 1).

It is obvious that vibrations of a conveyor are reducing the accuracy of a subsystem 5-6-7-8-9-1011- 3 / 12 operation. Hence, the suppression of undesired conveyor's vibrations is an effective tool for efficiency raise from all points of view.

The conveyor's vibrations have the permanent source like motor and other sources having exploitation nature. The electric drive motor is of $3.7 \mathrm{~kW}$ (see Fig. 2), providing for conveyor a maximum speed of transporting as $0.3 \mathrm{~m} / \mathrm{s}$.

Let's consider for basic explanation the simplest one-dimensional version of VEHD (see Fig. 3) Assume that an object (conveyor) could be modelled by one-degree-of-freedom system having mass $\mathrm{M}$, springing element with stiffness coefficient ko and viscous friction coefficient bo. A conveyor is vibrating along coordinate axis $\mathrm{X}$ as shown in Fig. 3, so the conveyor's movement coordinate is $\mathrm{X}(\mathrm{t})$, where $\mathrm{t}$ is time. 


\section{WwW.vntr.ru}

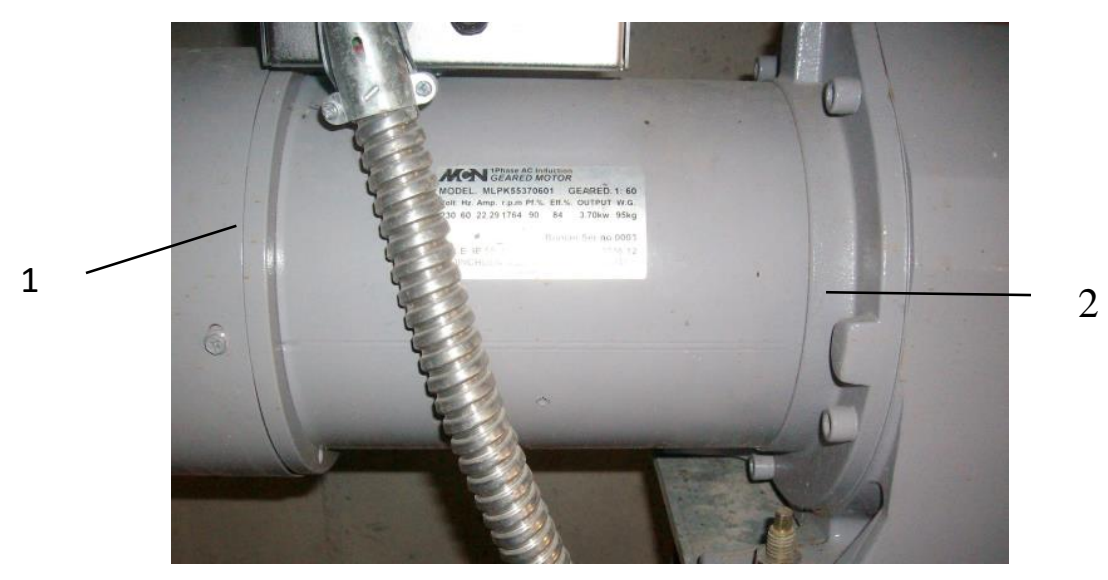

Fig. 2. The conveyor's motor. 1 - motor; 2 - flange

The body 1 of VEHD is attached firmly to object. VEHD consists of two major parts: tuned mass damper and alternator. The outer casing of VEHD is firmly attached to the conveyor, and the mass of casing is included in $M$. TMD $\mathrm{m}$ is connected to a casing by means of springs having the stiffness $k_{1}$ and the viscosity factor $b_{1}$. A mass $m$ is vibrating in the same direction as a mass $M$. The coordinate of vibrations of $m$ is $x(t)$. It is shown in $[3 ; 4]$ that the highest effectiveness of VEHD could be reached when $k_{1} / m=\omega_{0}^{2}$ is adjusted to variable external force frequency $\omega$, or $k_{1} / m=\omega^{2}$, however it must be used the special control device in this case providing measuring of the changing values $\omega$ and adjusting stiffness coefficient of spring $k_{1}$. In that case the magnitudes of $k_{1}$ would be variable. The diagram layout of that control device is shown in Figure1 by "magenta" subsystem 46-13-14-15.

The electromagnetic subsystem is the inducing current $\mathrm{i}$, and $\mathrm{L}$ is an inductance, $R$ is an electrical resistance, where $R_{\mathrm{c}}$ is a coil resistance and $R_{\mathrm{d}}$ is a load resistance, and $R=R_{\mathrm{c}}+R_{\mathrm{d}}$.

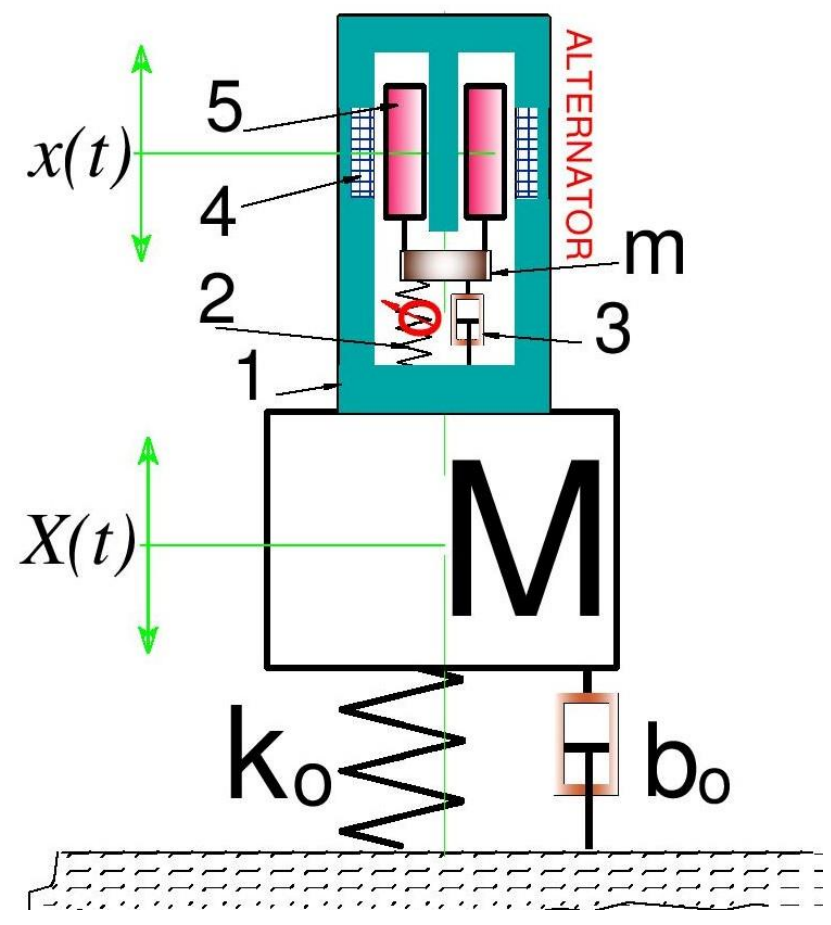

Fig. 3. One-dimensional VEHD 
Assume that the external excitation forces could be presented by term $H \sin (\omega t)$, where $H$ is the amplitude of external force and $\omega$ is the frequency. The system "VEHD and one-degree-of-freedom object" dynamics is described by a system of the ordinary differential equation with three variables $\mathrm{X}(\mathrm{t}), \mathrm{x}(\mathrm{t}), \mathrm{i}(\mathrm{t}), \quad$ (see for instance [3 - 5], [11], [12])

$$
\begin{gathered}
M \ddot{X}+b_{1}(\dot{X}-\dot{x})+j \omega^{2}(X-x)+b \dot{X}+k X=H \sin \omega t, \\
m \ddot{x}-b_{1}(\dot{X}-\dot{x})-j \omega^{2}(X-x)+F i=0, \\
L \dot{i}+R i-F(\dot{x}-\dot{X})=0
\end{gathered}
$$

where ${ }^{`}=\mathrm{d} / \mathrm{dt}$ and $F-$ linkage factor. The linkage factor could be determined in most cases as $F$ $=B L_{\mathrm{s}}$, where $B$ is field flux and $L_{\mathrm{s}}$ is characteristic size.

The system of equations (1) $-(3)$ includes the specific features: a. automatic frequency tuning $\omega \mathrm{O}=$ $\omega$ and $b$. the link between vibrations of tuned mass damping subsystem and dynamic behaviour of current generating subsystem (equation (3)). It gives the possibility be focused on the dynamic properties of TMD coupled to an alternator.

It was decided to make the preliminary vibration test for determination of possible resonances in a conveyor's discharge area. The tests were done in frequency range $0-100 \mathrm{~Hz}$ for vertical vibrations. It was registered one visible spike of $1.1 \mathrm{~mm}$ at $10.8 \mathrm{~Hz}$. The analysis shows that that situation (resonance at $10.8 \mathrm{~Hz}$ ) is due to framed structure of the belt conveyor transporting portion. All other amplitudes at other frequencies were negligible, so to be not worth considering. Hence, the accuracy of an arm operation would be dictated partially by this vibratory issue: the position of a transported product should be "fretted", deviated from central point periodically in range of $+/$ $1.1 \mathrm{~mm}$. The discovered situation gives an opportunity to build one-degree-of-freedom model of a conveyor and use the equation system (1) - (3) for dynamical study of total object.

Based on these results, received data and using the equation (1) it is possible to model the theoretical amplitude - frequency characteristic of an object vertical vibrations (green solid curve) as shown in Fig. 4. There is the abscissa axis for frequencies in $\mathrm{Hz}$, and ordinate axis for amplitude values (in millimetres). The amplitude - frequency characteristic in Figure 4 presents that peak of the amplitude (resonance) of $1.092 \mathrm{~mm}$ is measured at frequency $10.8 \mathrm{~Hz}$, so one can state that the built model reflects successfully the real dynamics.

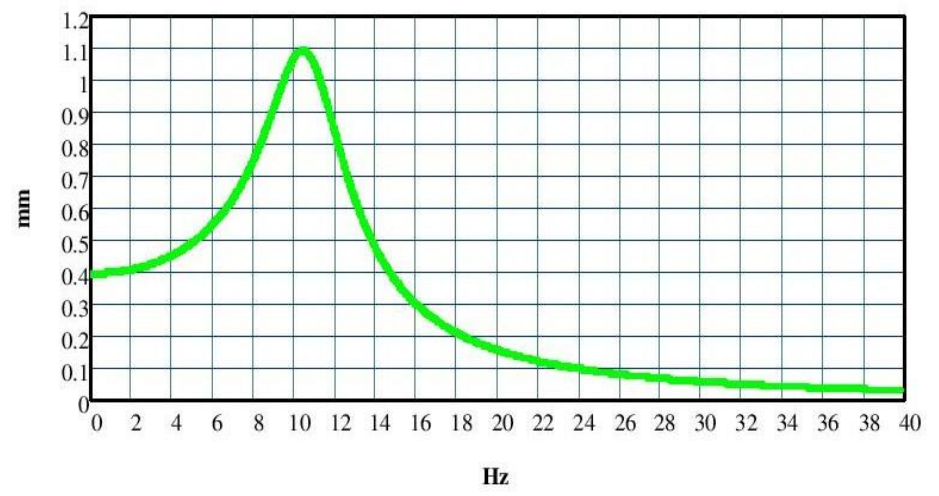

Fig. 4. Theoretical amplitude-frequency characteristics for examined conveyor

The received parameters allow select the design data for VEHD. Let's remind that the main purpose of VEHD is to satisfy two conditions: 1. a reduction of the heaving levels, 2. a generation of an additional electrical energy due to the heaving mitigation. After several probes it was decided that the designed movable mass $\mathrm{m}$ of TMD would be $279 \mathrm{~kg}$. The system of equations (1) - (3) was 
used for determination of main parameters of VEHD, keeping in mind that $k_{1} / m=\omega^{2}$ and numerical relationships of $[3 ; 4]$ for a calculation of an alternator parameters. Finally, the amplitude frequency characteristics of considered conveyor-feeder with implanted VEHD could be built (see Fig. 5) exploiting the system of differential equations (1) - (3). A green curve still reflects the dynamical behaviour of conveyor without installed VEHD, and this curve coincides to green curve in Figure 4 (the system of a coordinates in Fig. 5 is similar to a system of a coordinates in Fig. 4). The blue dotted curve in Figure 5 stands for the damped vibrations of a conveyor when VEHD is installed. The maximum damped amplitude (according to blue dotted line) is $0.585 \mathrm{~mm}$ at $7.7 \mathrm{~Hz}$, and the amplitude at original resonance point $(10.8 \mathrm{~Hz})$ is $0.45 \mathrm{~mm}$.

The brown dashed curve in Fig. 5 reflects TMD mass $m$ oscillations. The observer can see that TMD curve is repeating in some way the character of a conveyor damped vibration curve. The peak of TMD curve is equal to $3.533 \mathrm{~mm}$ at $8.9 \mathrm{~Hz}$. VEHD peak of useful power could be plotted by solid magenta curve (see Fig. 6). There is the abscissa axis for frequencies in $\mathrm{Hz}$, and ordinate axis for peak values of useful power (in $\mathrm{kW}$ ). VEHD useful power is calculating by formula $P(\omega)=0.5$ $R_{\mathrm{d}} i^{2}$, where $R_{\mathrm{d}}=0.72 R$. The peak of useful power is $1.63 \mathrm{~kW}$ at $10 \mathrm{~Hz}$.

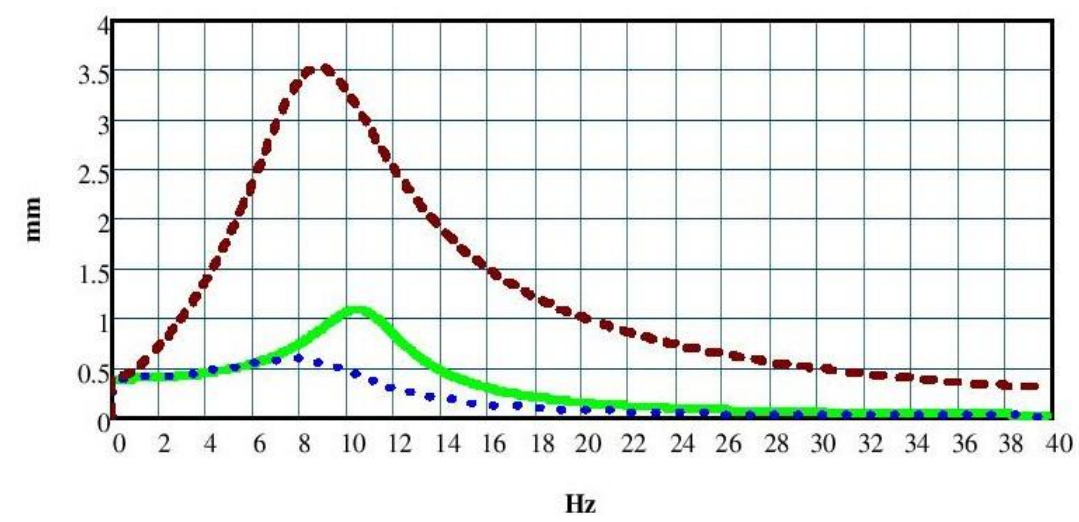

Fig. 5. Theoretical dynamical characteristics for a object when VEHD installed

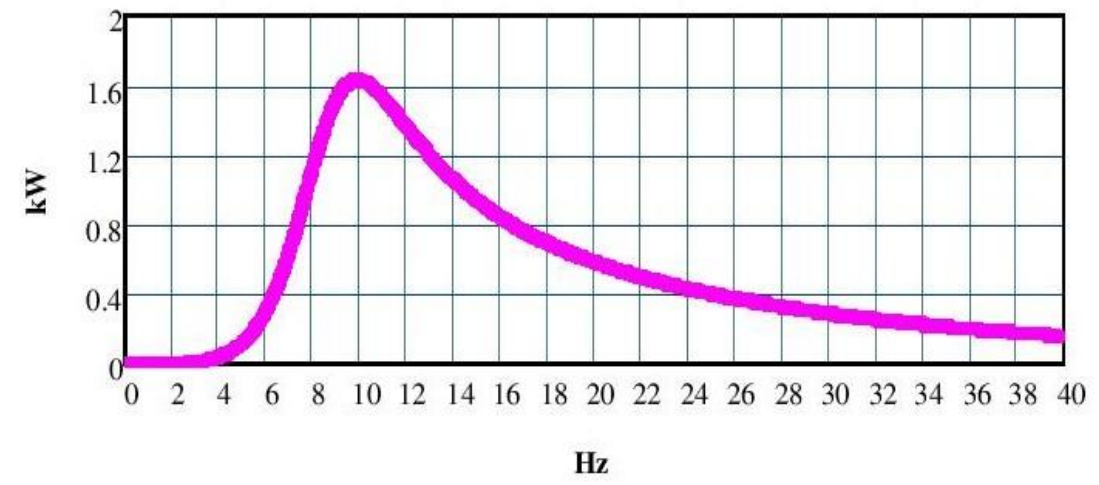

Fig. 6. Theoretical power characteristics for a object when VEHD installed

The prototype of VEHD focused on extracting the possibly maximum power from vibrating chassis was designed and fabricated. The design parameters were composed specifically for VEHD mounting at the discharge area vibrating in range of $0 \mathrm{~Hz}-40 \mathrm{~Hz}$. The selected mass of fabricated movable TMD part in VEHD was $1 / 4$ of model mass or $69.75 \mathrm{~kg}$. All other main characteristics were based on values presented in modelling case. Four units of VEHD were vertically installed close to perimeter of a discharge area. The photo of the test rig system master control box 
incorporating the designed scheme presented in Fig. 1 (without central computer) is shown in Fig. 7.

There is one peak only of $0.5 \mathrm{~mm}$ at $7.9 \mathrm{~Hz}$. The measured combined maximum value of useful power delivered by four VEHD is equal to $1.59 \mathrm{~kW}$.

The comparison of values metered during tests to data received theoretically shows that the deviation of obtained data from theoretically predicted is small; and it could be concluded that these results confirm a satisfactory compliance of dynamic and energy properties of real fabricated VEHD to theoretically predicted model.

As a result, one can see that the maximal values of amplitude of disturbing vibrations reduce from $1.1 \mathrm{~mm}$ (recorded at $10.8 \mathrm{~Hz}$ ) to $0.5 \mathrm{~mm}$ (recorded at $7.9 \mathrm{~Hz}$ ). It is a dual benefit - a reduction of amplitude in 2.2 times and shifting of the resonance frequency to lower magnitudes (from $10.8 \mathrm{~Hz}$ to $7.9 \mathrm{~Hz}$ ). Hence, the overall vibration acceleration is reduced in 4.11 times. These issues provide the increase of effectiveness and accuracy of the arm manipulation. Also, the system can generate for free the additional $1.6 \mathrm{~kW}$. The presented VEHD could be considered as a module easy for population at the agricultural engineering practice.
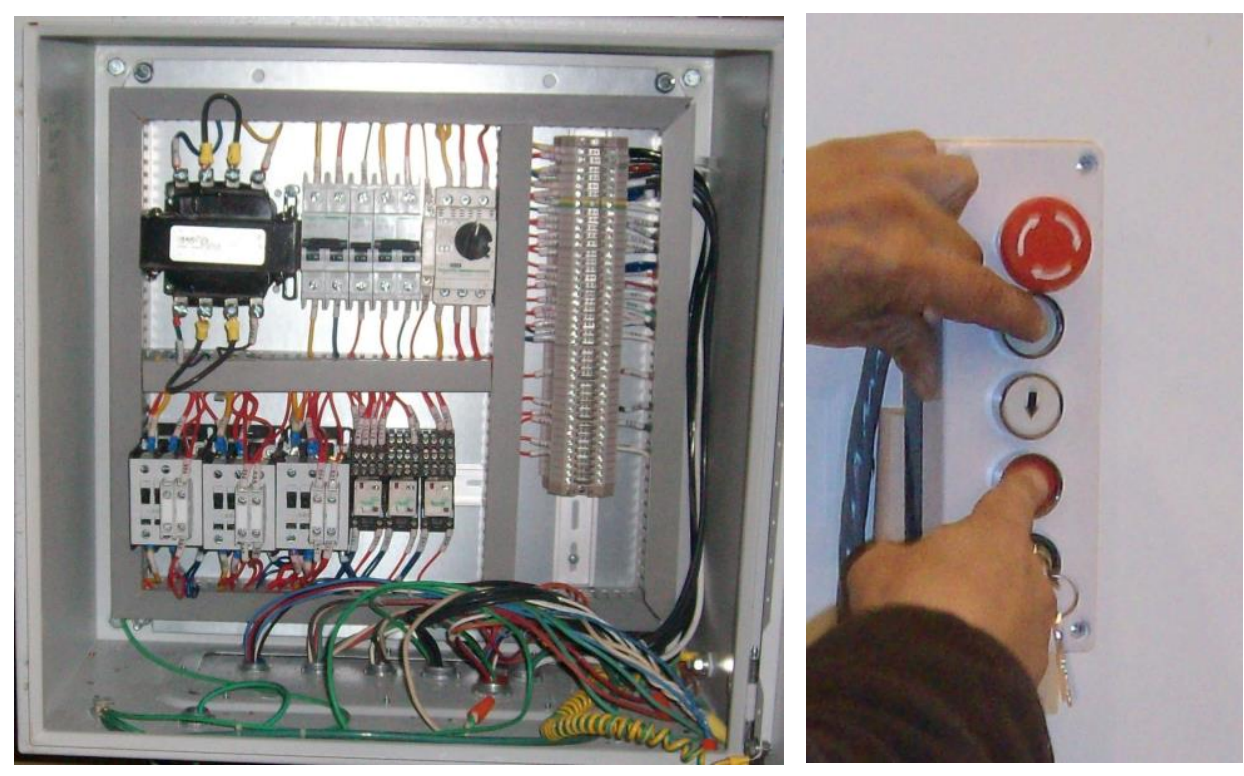

Fig. 7. Master control system box (left) and safety control panel (right)

There is one peak only of $0.5 \mathrm{~mm}$ at $7.9 \mathrm{~Hz}$. The measured combined maximum value of useful power delivered by four VEHD is equal to $1.59 \mathrm{~kW}$.

The comparison of values metered during tests to data received theoretically shows that the deviation of obtained data from theoretically predicted is small; and it could be concluded that these results confirm a satisfactory compliance of dynamic and energy properties of real fabricated VEHD to theoretically predicted model.

As a result, one can see that the maximal values of amplitude of disturbing vibrations reduce from $1.1 \mathrm{~mm}$ (recorded at $10.8 \mathrm{~Hz}$ ) to $0.5 \mathrm{~mm}$ (recorded at $7.9 \mathrm{~Hz}$ ). It is a dual benefit - a reduction of amplitude in 2.2 times and shifting of the resonance frequency to lower magnitudes (from $10.8 \mathrm{~Hz}$ to $7.9 \mathrm{~Hz}$ ). Hence, the overall vibration acceleration is reduced in 4.11 times. These issues provide the increase of effectiveness and accuracy of the arm manipulation. Also, the system can generate for free the additional $1.6 \mathrm{~kW}$. The presented VEHD could be considered as a module easy for population at the agricultural engineering practice. 


\section{Conclusions}

1. The developed vibration energy harvesting dampers completed with the special control device of a springing element provide the efficient solution for a performance improvement of the agricultural belt conveyor-feeder systems.

2. The provided solution allows to solve multiple problems in the belt conveyor-feeder systems:

- the arm's functioning with increased performance and perfect accuracy during outgoing product handling;

- the arm's functioning with a minimal energy consumption;

- the additional electrical power generation using the suppressed vibrations of the operating belt conveyor-feeder;

- the increasing of the lifetime of all systems in operating belt conveyor-feeder.

3. The proposed approach gives the tool to combat the extensive inertia forces, aerodynamic resistances, wind loads, and other loads, which could be registered during belt conveyor-feeder systems operation.

\section{References}

[1] Nerubenko G.P., Trunin S.F. Design of robot's drives. Textbook. Publisher: Shipbuilding Institute. Nikolaev, 1985. - 41 p. (in Russian)

[2] Нерубенко Г. П., Ватипко Б. А., Щур П. А., Справочник по перегрузочному оборудованию на морском транспорте (The handbook of loading equipment in marine transport). / 221 с. ил. - Одесса: Маяк, 1990 (in Russian).

[3] Bograd, A, Nerubenko, G, Nerubenko,C. Energy Harvesting in Vehicle's Drive. Proceedings of the 2nd International Conference of Energy Harvesting, Storage, and Transfer (EHST'18). Niagara Falls, Canada, Paper No. 112 (2018).

[4] Nerubenko et al. Tuned mass dampers as energy harvesters for railways. Proceedings of ISMA 2018 and USD2018. Leuven, Belgium. pp. 1689-1702 (2018)

[5] Nerubenko G., Krupenin V., Nerubenko C. Vehicle Hybrid Free - Piston Engine - Generator. 16 ${ }^{\text {th }}$ International Scientific Conference "ENGINEERING FOR RURAL DEVELOPMENT". Proceedings. Jelgava, Latvia, May 24.-26, 2017. p. p. 114-120

[6] Nerubenko et al. "Vibration Energy Harvesting Damper". U.S. Patent Application No. 16/119,346. 08.31, 2018.

[7] Priya S., Inman D. L.. Energy Harvesting Technologies. Sprinder. Verlag. 2009

[8] Cottone F., Energy Harvesting: introduction. NiPS Summer School 2015 - July 7-12th -Fiuggi (Italy). $50 \mathrm{p}$.

[9] Ojha S. et al. Performance Monitoring of Vibration in Belt Conveyor System. Journal of Engineering Research and Applications. Vol. 4, Issue 7(Version 6), July 2014, pp.22-31

[10] Cottone F. et al. Energy harvester apparatus having improved efficiency. US Patent 8350394. 01.08.13

[11] Patel P., Development of Electromagnetic Micro-Energy Harvesting Device. Thesis. University of Waterloo. Waterloo, Ontario, Canada, 2013.

[12] Nerubenko, G., Gurevych, D., and Kolomier, P., Dynamics of Amphibious All-Terrain Vehicle's Chassis Having Vibration Energy Harvesting Dampers. SAE Technical Paper 2019-01-1510, 2019, doi:10.4271/2019-01-1510.

Дата поступления: 3 мая 2019 г. 